\title{
Manifestations of Hyperprolactinoma and its Management by Bromocriptine and Cabergoline
}

\author{
Faiza A. Qari, FRCP, ABIN \\ Department of Medicine, Faculty of Medicine \\ King Abdulaziz University, Jeddah, Saudi Arabia \\ faiza_qari@yahoo.co.uk
}

\begin{abstract}
This is a prospective study analyzing gender differences in the presentation of hyperprolactinemia as well as the efficacy and tolerance to cabergoline and bromocriptine. Thirty-six patients (23 women, 13 men) were recruited and divided into two groups; Group One received bromocriptine and Group Two received cabergoline for three months. The prolactin level was measured before and after treatment in both groups. Galactorrhea and infertility were more common symptoms in women; however, $100 \%$ of men with micro or macroprolactinoma had libido disturbances. The prolactin level was higher in men than in women whether they exhibited macro $(7640 \pm 80 v s .6230 \pm 71 \mathrm{ng} / \mathrm{mL})$ or microprolactinomas $(6167 \pm 895$ vs. $5998 \pm 775 \mathrm{ng} / \mathrm{mL})$. The prolactin level was significantly higher in women with non-tumor hyperprolactinemia $(3390 \pm 164 v s .1279 \pm 53, \mathrm{p}=0.038)$. The mean serum prolactin level was significantly decreased in both groups whether they received bromocriptine or cabergoline $(5790 \pm 370 v s$. $2725 \pm 124 \mathrm{ng} / \mathrm{mL} ; \mathrm{p}=0.001)$. The prolactin reduction was more prominent in the cabergoline group whether in men or women, than in the bromocriptine group at the end of the three months of treatment $(5791 \pm 723$ vs. $1725 \pm 318 \mathrm{ng} / \mathrm{mL} ; \mathrm{p}=0.001)$.
\end{abstract}

Keywords: Hyperprolactinemia, Prolactinomas, Bromocriptine, Cabergoline.

\section{Introduction}

Prolactinomas represent the most common type of pituitary tumor ${ }^{[1]}$, however, they are relatively rare in males as more than $70 \%$ of the cases occur in women. Gender differences with regards to tumor size also exist

Correspondence \& reprint request to: Dr. Faiza A. Qari

P.O. Box 13042, Jeddah 21943, Saudi Arabia

Accepted for publication: 26 March 2008. Received: 20 January 2008. 
in hyperprolactinemia; microadenomas are commonly found in women, while macroadenomas are more commonly found in men ${ }^{[2]}$. Women with minor elevations in serum prolactin levels often have classic symptoms of ovulatory dysfunction in the form of amenorrhea-galactorrhea syndrome. This facilitates early diagnosis in women ${ }^{[3]}$. Conversely, in men with hypogonadism symptoms of a decreased libido, sexual dysfunction and abnormal semen analysis are found. This is often overlooked and the diagnosis is often delayed ${ }^{[4]}$. The delay in diagnosis was suggested not to be the only difference between men and women ${ }^{[5]}$. Rapidly growing prolactinomas with increased markers of cellular proliferation have recently been reported to occur more often in men, suggesting more aggressive prolactinomas in men compared to women ${ }^{[6]}$.

Prolactinomas can be treated with drug therapy, surgery, or radiation therapy. Surgical resection of the adenoma is usually associated with a risk of recurrence in all patients. Hyperprolactinemia recurs one to five years after surgery in $10 \%-50 \%$ of patients with microprolactinomas and in $20 \%-90 \%$ of patients with macroprolactinomas ${ }^{[7]}$. Radiotherapy rarely results in the restoration of normal serum prolactin concentrations and therefore is generally not considered as a primary treatment for prolactinomas. For this reason, it is reserved for patients with tumors that persistently grow despite medical or surgical treatment ${ }^{[8]}$.

The standard treatment of hyperprolactinemia is the semisynthetic ergot alkaloid bromocriptine, which was introduced in 1971. It is an orally active dopamine agonist that not only inhibits the synthesis and secretion of prolactin but also reduces cellular DNA synthesis and tumor growth. Because of its short half-life, bromocriptine must be given two or three times daily. It is a cheap drug; however, it has some adverse effects such as headache, dizziness and nausea, and cannot be tolerated by $10 \%$ of patients. In addition, bromocriptine is not sufficient to normalize hyperprolactinemia in some patients ${ }^{[9]}$. Cabergoline is another potent ergot derivative that selectively binds to dopamine D2 receptors and has a long plasma half-life that enables once or twice - weekly administrations ${ }^{10]}$. Cabergoline in doses of 0.5 to $1 \mathrm{mg}$ twice weekly can normalize the serum prolactin in $83 \%$ of patients ${ }^{[11]}$.

The aim of this prospective study was to investigate gender differences in the etiology, clinical, biochemical and radiological 
presentations of hyperprolactinemia. The efficacy of cabergoline to the standard regimen of bromocriptine was also compared. The dopamine agonists were given for three months in two groups of patients with microprolactinomas, macroprolactinomas or idiopathic hyperprolactinemia in a series of patients attending the medical clinic at King Abdulaziz University Hospital (KAUH) in Jeddah, Saudi Arabia.

\section{Methodology}

Data from 36 patients attending the medical clinic KAUH in Jeddah with the diagnosis of hyperprolactinemia confirmed by immunoradiometric assays were included in the study. The diagnostic criteria for macroprolactinomas included a mean serum prolactin level (PRL) levels of at least $200 \mathrm{ng} / \mathrm{mL}$ and pituitary tumor $\geq 1 \mathrm{~cm}$ in diameter on computerized tomography (CT) or magnetic resonance imaging (MRI) scans; for microprolactinomas serum PRL levels $\leq 200 \mathrm{ng} / \mathrm{mL}$ and pituitary tumor $<1 \mathrm{~cm}$ in diameter; for non-tumor hyperprolactinemia, serum prolactin level was above normal with a normal pituitary at MRI, with no other explanation for increased prolactin such as primary hypothyroidism or drug-induced hyperprolactinemia.

Hormone Measurements: Hormone measurements were performed in the hospital laboratory using standard radioimmunoassay (RIA) method using commercial kits. Serum prolactin was measured before and at the end of the study. The upper limit of normal range for PRL was 175 $\mathrm{ng} / \mathrm{mL}$ for men and $225 \mathrm{ng} / \mathrm{mL}$ for women.

Radiology: MRI using the maximum craniocaudal diameter obtained in coronal sections evaluated tumor size. Tumors larger than $4 \mathrm{~cm}$ in diameter were called giant tumors. The term invasive was restricted to adenomas showing cavernous sinus invasion at radiological evaluation or at surgery. The radiological criterion used for sinus invasion was visualization of the tumor extending to the lateral margin of the carotid artery and surrounding it.

Visual Perimetry: In all macroprolactinomas, the assessment of visual filed using Goldmann-Friedmann perimetry was performed.

Protocol of Medical Treatment: Thirty-four patients with hyperprolactinemia, whose serum prolactin level was above normal limit on two occasions, were assigned to one of two groups. Group One 
received bromocriptine and Group Two received cabergoline for three months. Twelve patients ( 9 women, 3 men) received bromocriptine. Twenty-two patients (13 women, 9 men) received cabergoline. Bromocriptine was started at a dose of $2.5 \mathrm{mg}$ twice daily, and cabergoline at a dose of $0.25 \mathrm{mg}$ twice weekly. Subsequently, the dose of bromocriptine was increased to $5 \mathrm{mg}$ twice daily and cabergoline to 0.5 mg twice weekly in the third week of the study and was continued until the end of the study.

Statistical Analysis: Data was reported as mean \pm SD. The statistical analysis was performed with the Statistical Package for Social Sciences program (SPSS) for Windows using analysis of variance of the frequency of observations between men and women compared by $\chi^{\text {two }}$ tests and Fischer's exact probability where appropriate. The level of significance was set at $p<0.05$.

\section{Results}

Basal clinical characteristics in men and women are shown in Table 1. Macroprolactinomas were more common in men than women $(30 \%$ vs. $17.3 \%$ ); similarly, microprolactinomas were more frequent in men than women ( $66 \%$ vs. 53\%); however, non-tumor hyperprolactinemia $(26 \%$ vs. 15\%) were more frequent in women (Table 1$)$.

Table 1. Baseline number of patients in bromocriptine and cabergoline groups.

\begin{tabular}{l|c|c}
\hline \multicolumn{1}{c|}{ Parameter } & Bromocriptine & Cabergoline \\
\hline No. of Patients & 12 & 22 \\
\hline Men & 3 & 9 \\
\hline Women & 9 & 13 \\
\hline Microprolactinomas & 8 & 12 \\
\hline Macroprolactinomas & 3 & 5 \\
\hline Non tumor Hyperprolactinemia & 1 & 5 \\
\hline
\end{tabular}

Visual Field Defect: Amongst individuals with macroprolactinoma, $40 \%$ of the men had visual field defect (one had tunnel vision and the second one had bi-temporal hemianopia. However, none of the women with macroprolactinomas had visual field defect.

Prolactin Level: The prolactin level was not significantly higher in men than women bearing either macro- or microprolactinomas. However, serum prolactin level was significantly higher in women with 
non-tumor hyperprolactinemia compared to men (3390 vs. $1279 \mathrm{ng} / \mathrm{mL})$ with $\mathrm{p}=0.038$ (Table 2).

Table 2. Patient's profile of the study expressed as means \pm S.D.

\begin{tabular}{l|c|c|c}
\hline \multicolumn{1}{c|}{ Parameter } & Women & Men & $p$ Value \\
\hline Total number of patients & 23 & 13 & 0.19 \\
\hline Mean \pm SD & $36 \pm 10$ & $41 \pm 11$ & \\
\hline Macroprolactinomas & 4 & 4 & 0.4 \\
\hline Mean age \pm SD & $35 \pm 5.5$ & $41 \pm 8.5$ & 0.66 \\
\hline Basal prolactin level & $6230 \pm 71$ & $7640 \pm 80$ & 0.7 \\
\hline Maximum tumor diameter & $19.5 \pm 4$ & $21 \pm 16$ & 0.25 \\
\hline Microprolactinomas & 12 & $44 \pm 14$ & 0.87 \\
\hline Mean age \pm SD & $37 \pm 12$ & $6167 \pm 895$ & 0.05 \\
\hline Basal prolactin level & $5998 \pm 775$ & $3.9 \pm 2$ & \\
\hline Maximum tumor diameter & $2.25 \pm 0.88$ & 2 & 0.107 \\
\hline Non tumor hyperprolactinemia & 6 & $40 \pm 12$ & 0.038 \\
\hline Mean age \pm SD & $31 \pm 7$ & $1279 \pm 53$ & \\
\hline Basal prolactin level (ng/mL) & $3390 \pm 164$ & & \\
\hline
\end{tabular}

Tumor Diameter: Maximum tumor diameter was not significantly higher in men with macroprolactinomas compared to their female counterparts. However, it was significantly larger in men with microprolactinomas compared to women (p value 0.05) (Table 2).

Clinical Presentations: Galactorrhea was reported in both micro and macroprolactinomas, while infertility was more common in women. Panhypopituitarism was reported only in macroprolactinemia and was more common in men. Almost all men with micro or macroprolactinomas had libido disturbances (Table 3).

Comparison of the Effect of Cabergoline and Bromocriptine on Prolactin Level: Mean serum prolactin levels were significantly decreased in both groups $(5790 \pm 370 v s .2725 \pm 124, \mathrm{p}=0.0010)$. The prolactin reduction after the treatment was more prominent in the cabergoline group than in the bromocriptine group at the end of the three months of treatment (cabergoline reduction was $5791 \pm 723$ vs. $1725 \pm$ $318(\mathrm{p}=0.001)$ compared with bromocriptine $(4025 \pm 301$ vs. $2753 \pm$ 233 , $p$ value 0.33 ) (Table 4). The rate of normalization of serum prolactin was higher in the cabergoline group (14 patients, 63\%) than in bromocriptine group (5 patients, 41\%). Adverse effects were less frequent in the cabergoline group than in bromocriptine group. Five 
patients $(40 \%)$ in the bromocriptine group reported drug related adverse effects such as dizziness and nausea. Yet, only three patients (13.6\%) in the cabergoline group complained of dizziness. Adverse effects generally occurred in the first week of treatment and resolved with time. However no patients stopped their treatment during the period of study.

Table 3. Clinical presentations: Presenting symptoms expressed as the number of individual patients with prevalence in percentage.

\begin{tabular}{l|c|c}
\hline \multicolumn{1}{c}{ Parameter } & Women & Men \\
\hline Macroprolactinomas & 4 & 4 \\
\hline Galactorrhea/Gynecomastia & $1(25 \%)$ & 0 \\
\hline Infertility & $3(75 \%)$ & $2(50 \%)$ \\
\hline Irregular period & $3(75 \%)$ & - \\
\hline Libido disturbance & - & $3(75 \%)$ \\
\hline Panhypopituitarism & $2(50 \%)$ & $3(75 \%)$ \\
\hline Microprolactinomas & 12 & 8 \\
\hline Galactorrhea & $5(41 \%)$ & $1(12.5 \%)$ \\
\hline Infertility & $5(41 \%)$ & $2(25 \%)$ \\
\hline Irregular period & $8(66 \%)$ & - \\
\hline Libido disturbance & - & $1(100 \%)$ \\
\hline Gynecomastia & - & 2 \\
\hline Non tumor hyperprolactinemia & 6 & - \\
\hline Galactorrhea & $1(16.6 \%)$ & $1(50 \%)$ \\
\hline Infertility & $3(50 \%)$ & - \\
\hline Irregular period & $5(83.3 \%)$ & $2(100 \%)$ \\
\hline Libido disturbance & - & \\
\hline
\end{tabular}

Table 4. Changes in serum prolactin levels (means \pm S.D) in the bromocriptine and cabergoline group before and after the study.

\begin{tabular}{l|c|c|c}
\hline \multicolumn{1}{c|}{ Parameter } & $\begin{array}{c}\text { Prolactin level (ng/ml) } \\
\text { before treatment }\end{array}$ & $\begin{array}{c}\text { Prolactin level (ng/ml) } \\
\text { after treatment }\end{array}$ & $\begin{array}{c}\mathbf{p} \\
\text { Value }\end{array}$ \\
\hline All Patients & $5790 \pm 370$ & $2725 \pm 124$ & 0.001 \\
\hline Bromocriptine Group & $4025 \pm 301$ & $2753 \pm 233$ & 0.33 \\
\hline Cabergoline Group & $5791 \pm 732$ & $1725 \pm 318$ & 0.001 \\
\hline
\end{tabular}

\section{Discussion}

Gender differences in the etiology and clinical presentation of hyperprolactinemia in the two groups were observed. There was also a difference in the tumor diameter by MRI between men and women. Non-tumor hyperprolactinemia was less frequent than micro- and 
macroprolactinomas. Microprolactinomas were more frequent in men in our study group; however, most studies have found microprolactinomas to be more frequent in women ${ }^{[2]}$. Macroprolactinomas were more frequent in men. The frequency of macroprolactinomas in men remains controversial in the literature. In fact, some studies have reported equal distribution of macroprolactinomas between genders; others have found a higher prevalence in men compared to women ${ }^{[12]}$.

There was no significant difference in the age at presentation in men and women with microprolactinomas or macroprolactinomas. Age at presentation for men in our study was 40 years or older, which was similar to that reported by other series like Pinzone et al. and Berezin et al. $^{[13,14]}$.

Clinical symptoms at presentation differed according to gender. Infertility and galactorrhea were more frequent in women. Libido disturbances were reported in almost $100 \%$ of male patients, while interestingly, no women complained of this symptom. As expected, it was found that hypopituitarism and visual field defects were frequent in patients with macroprolactinomas than those with microprolactinomas. It was also observed more frequently in men with macroprolactinomas than in women ${ }^{[15,16]}$.

In previous studies, tumor size did not seem to be associated with duration of symptoms, and the patient's age did not correlate with tumor size in either micro or macroprolactinomas ${ }^{[17]}$. It has been suggested that macroprolactinomas have more aggressive growth characteristics in men compared with women, since markers of cellular proliferation such as $\mathrm{Ki}$ -67 and proliferation cell nuclear antigen were more heavily expressed in prolactinomas growing in men than those in women ${ }^{[18]}$. However, the possibility that gender-related factors modify the rate of tumor growth cannot be ruled out by the results of this study. It has not been found that there was any connection between the severities of neurological signs as expression of tumor invasiveness according to gender. This study has noted that men had larger tumors especially with microprolactinomas, which also correlated with a higher prolactin level in men compared to women $^{[19,20]}$.

This was a prospective, randomized study comparing the efficacy and tolerability of cabergoline and bromocriptine in patients with hyperprolactinemia secondary to microprolactinomas, macroprolactin- 
omas or idiopathic at KAUH. The shortcomings of this study are the small number of patients and the short duration of treatment. Mean serum prolactin levels were significantly decreased in all patients after treatment with a $\mathrm{p}$ value of 0.001 . Prolactin reduction was more prominent in the cabergoline group than in the bromocriptine group at the end of three months of treatment with a significant $p$ value of 0.001 . Three months treatment resulted in a higher rate of normalization of serum prolactin in the cabergoline group, in comparison with the bromocriptine group $(63 \%$ vs. $40 \%$ ). These results clearly indicate that cabergoline is superior to bromocriptine in terms of both normalization rate and the mean suppressibility of elevated prolactin ${ }^{[21,22]}$. In some studies, tumor shrinkage has been reported. Because this study was relatively shortterm (only three months), MRI imaging was not repeated at the end of the study ${ }^{[23]}$. More side effects were observed in the bromocriptine group than the cabergoline group $(40 \% \text { vs. } 16.6 \%)^{[24,25]}$. The side effects in these patients were much lower than other studies, which may be explained by lowering the doses of bromocriptine and cabergoline ${ }^{[26]}$. The outcome of treatment evaluated according to the etiology and gender was similar in both men and women. The corresponding data reiterates the concept that cabergoline is an effective drug in men and women. Cabergoline is more effective and tolerable than bromocriptine at usual treated doses.

\section{Conclusion}

In patients with idiopathic, microprolactinomas or macroprolactinomas related hyperprolactinemia, in this study has shown that cabergoline is more effective and better tolerated than bromocriptine. Furthermore, its long-lasting effect makes it easy to use. For these reasons, cabergoline appears to be a reasonable alternative for patients in whom bromocriptine is not sufficiently efficacious or not well tolerated. For patients with financial difficulties, bromocriptine may be used as it is a cheaper alternative.

\section{References}

[1] Colao A, Lombardi G. Growth-hormone and prolactin excess. Lancet 1998; 352(9138): 1455-1461.

[2] Delgrange E, Trouillas J, Maiter D, Donckier J, Tourniaire J. Sex-related difference in the growth of prolactinomas: a clinical and proliferation marker study. J Clin Endocrinol Metab 1997; 82(7): 2102-2107. 
[3] Zargar AH, Laway BA, Masoodi SR, Bhat MH, Wani AI, Bashir MI, Salahuddin M, Rasool R. Clinical and etiological profile of hyperprolactinemia--data from a tertiary care centre. J Assoc Phyicians India 2005; 53: 288-290.

[4] De Rosa M, Zarrilli S, Vitale G, Di Somma C, Orio F, Tauchmanova' L, Lombardi G, Colao A. Six months of treatment with cabergoline restores sexual potency in hyperprolactinemic males: an open longitudinal study monitoring nocturnal penile tumescence. J Clin Endocrinol Metab 2004; 89(2): 621-625.

[5] Calle-Rodrigue RD, Giannini C, Scheithauer BW, Lloyd RV, Wollan PC, Kovacs KT, Stefaneanu L, Ebright AB, Abboud CF, Davis DH. Prolactinomas in male and female patients: a comparative clinicopathologic study. Mayo Clin Proc 1998; 73(11): 10461052.

[6] Biller BM. Diagnostic evaluation of hyperprolactinemia. J Reprod Med 1999; 44(12 Suppl): 1095-1099.

[7] Losa M, Mortini P, Barzaghi R, Gioia L, Giovanelli M. Surgical treatment of prolactinsecreting pituitary adenomas: early results and long-term outcome. J Clin Endocrinol Metab 2002; 87(7): 3180-3186.

[8] Biller BM, Luciano A, Crosignani PG, Molitch M, Olive D, Rebar R, Sanfilippo J, Webster $\mathbf{J}$, Zacur $\mathbf{H}$. Guidelines for the diagnosis and treatment of hyperprolactinemia. $J$ Reprod Med 1999; 44(12 Suppl): 1075-1084.

[9] Velasco M, Luchsinger A. Dopamine: pharmacologic and therapeutic aspects. Am J Ther 1998; 5(1): 37-43.

[10] Rains CP, Bryson HM, Fitton A. Cabergoline. A review of its pharmacological properties and therapeutic potential in the treatment of hyperprolactinemia and inhibition of lactation. Drugs 1995; 49(2): 255-279.

[11] Maurer RA. Dopaminergic inhibition of prolactin synthesis and prolactin messenger RNA accumulation in cultured pituitary cells. J Biol Chem 1980; 255(17): 8092-8097.

[12] Colao A, Sarno AD, Cappabianca P, Briganti F, Pivonello R, Somma CD, Faggiano A, Biondi B, Lombardi G. Gender differences in the prevalence, clinical features and response to cabergoline in hyperprolactinemia._Eur J Endocrinol 2003; 148(3): 325-331.

[13] Pinzone JJ, Katznelson L, Danila DC, Pauler DK, Miller CS, Klibanski A. Primary medical therapy of micro- and macroprolactinomas in men. J Clin Endocrinol Metab 2000; 85(9): 3053-3057.

[14] Berezin M, Shimon I, Hadani M. Prolactinoma in 53 men: clinical characteristics and modes of treatment (male prolactinoma). J Endocrinol Invest 1995; 18(6): 436-441.

[15] Hankins CA, Zamani AA, Rumbaugh CL. Prolactinomas. Clinical presentation, radiologic assessment and therapeutic options. Invest Radiol 1985; 20(4): 345-354.

[16] Ciccarelli E, Camanni F. Diagnosis and drug therapy of prolactinoma. Drugs 1996; 51(6): 954-965.

[17] Schlechte JA. Long-term management of prolactinomas. J Clin Endocrinol Metab 2007; 92(8): 2861-2865.

[18] Honegger J, Prettin C, Feuerhake F, Petrick M, Schulte-Mönting J, Reincke M. Expression of Ki-67 antigen in nonfunctioning pituitary adenomas: correlation with growth velocity and invasiveness. J Neurosurg 2003; 99(4): 674-679.

[19] Wu ZB, Yu CJ, Su ZP, Zhuge QC, Wu JS, Zheng WM. Bromocriptine treatment of invasive giant prolactinomas involving the cavernous sinus: results of a long-term follow up. J Neurosurg 2006; 104(1): 54-61.

[20] Jackson J, Safranek S, Daugird A. Clinical inquiries. What is the recommended evaluation and treatment for elevated serum prolactin? J Fam Pract 2005; 54(10): $897-$ 898, 901.

[21] Di Sarno A, Landi ML, Cappabianca P, Di Salle F, Rossi FW, Pivonello R, Di Somma C, Faggiano A, Lombardi G, Colao A. Resistance to cabergoline as compared with 
bromocriptine in hyperprolactinemia: prevalence, clinical definition, and therapeutic strategy. J Clin Endocrinol Metab 2001; 86(11): 5256-5261.

[22] Verhelst J, Abs R, Maiter D, van den Bruel A, Vandeweghe M, Velkeniers B, Mockel J, Lamberigts G, Petrossians P, Coremans P, Mahler C, Stevenaert A, Verlooy J, Raftopoulos C, Beckers A. Cabergoline in the treatment of hyperprolactinemia: a study in 455 patients. J Clin Endocrinol Metab 1999; 84(7): 2518-2522.

[23] Webster J, Piscitelli G, Polli A, Ferrari CI, Ismail I, Scanlon MF. A comparison of cabergoline and bromocriptine in the treatment of hyperprolactinemic amenorrhea. Cabergoline Comparative Study Group. N Engl J Med 1994 6; 331(14): 904-909.

[24] Bolko P, Jaskuła M, Waśko R, Wołuń M, Sowiński J. The assessment of cabergoline efficacy and tolerability in patients with pituitary prolactinoma type. Pol Arch Med Wewn 2003; 109(5): 489-495.

[25] Pellegrini I, Rasolonjanahary R, Gunz G, Bertrand P, Delivet S, Jedynak CP, Kordon C, Peillon F, Jaquet P, Enjalbert A. Resistance to bromocriptine in prolactinomas. $J$ Clin Endocrinol Metab 1989; 69(3): 500-509.

[26] Cannavò S, Curtò L, Squadrito S, Almoto B, Vieni A, Trimarchi F. Cabergoline: a first-choice treatment in patients with previously untreated prolactin-secreting pituitary adenoma. J Endocrinol Invest 1999; 22(5): 354-359. 


\section{أعر اض ارتفاع هرمون الحليب و علاجه}

\section{فايزة عبدالعزيز قاري}

قسم الطب، كلية الطب، جامعة الدلك عبدالعزيز

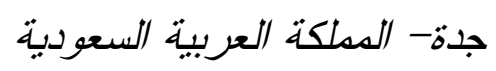

المستخلص. الدر اسة مستقبلية لمقارنة الاختلاف الجنسي من الناحية

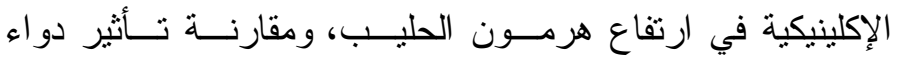

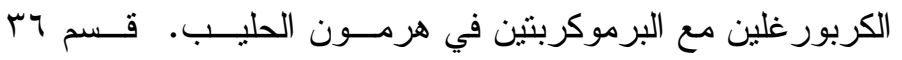

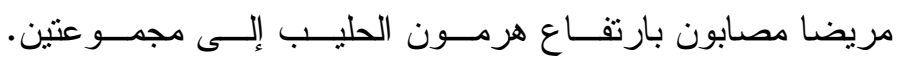
المجموعة الأولى عولجت بدو اء البرموكربتين، و المجموعة الثانية بونية

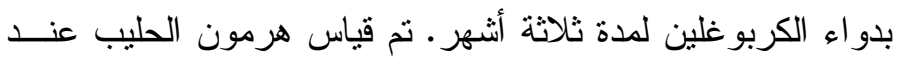

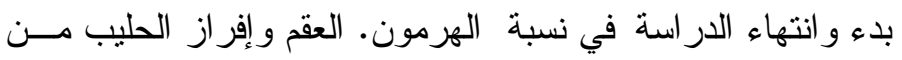

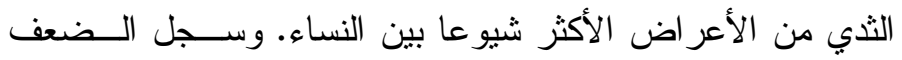

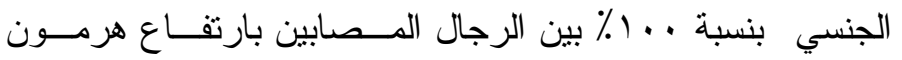

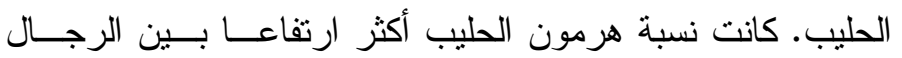

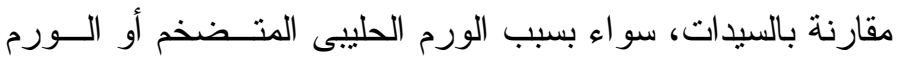

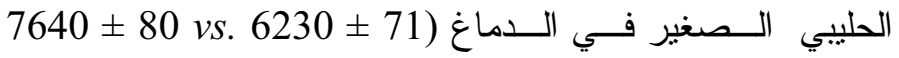
(6167 \pm 895 vs. $5998 \pm 775 \mathrm{ng} / \mathrm{mL}) .(\mathrm{ng} / \mathrm{mL}$

سجلت نسبة ارتقاع هورمون الحليب ارتفاعًا ذا دلالة إحصائية

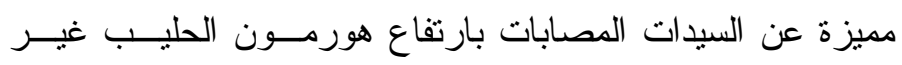

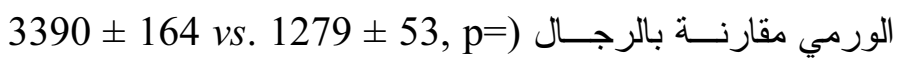
0.038). سجل انخفاض هورمون الحليــب بنــسبة ذات ذات دلالــــة

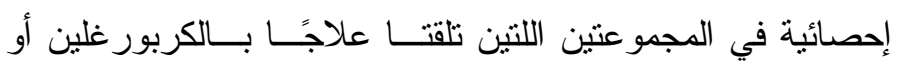

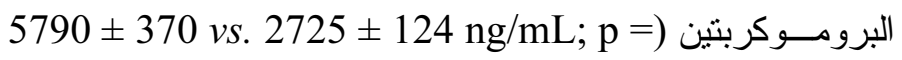
0.001). كانت نسبة انخفاض هرمون الحليب بنـسبة إحـصائية 
مميزة في مجموعة الكربورغلين سواء في الرجــال أو الــسيدات، مقارنة بنسبة انخفاض هرمون الحليب مع دو اء بروموكربتين فـي لـي لئي

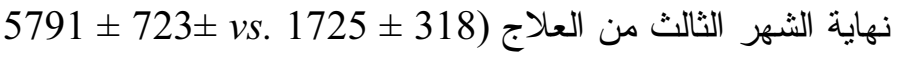
.(ng/mL ; p $=0.001$ 